\title{
Appraising the Perception of Science Teachers towards the Implementation of Entrepreneurial Science Education in Secondary Schools in Akwa Ibom State, Nigeria
}

\author{
Iniobong F. Akpan, Patrick J. Uko \\ Akwa Ibom State University \\ Nigeria
}

\begin{abstract}
The study sought to appraise the perception of science teachers' towards the implementation of entrepreneurial science education, the effects on individual students, society and the way forward in public secondary schools in Akwa Ibom State, Nigeria. The study adopted the survey research design. The population for the study were all science teachers in the 243 public secondary schools in the state. A sample size of two hundred and ten (210) was used. Three research questions were raised to guide the study. The instrument for data collection was the researchers developed questionnaire titled "Science Teachers Perceived Factors Hindering the Implementation of Entrepreneurial Science Education and its Influence on Individual Student and Society Questionnaire" (STEPFHIESES). Data collected were analysed using mean and standard deviation. The findings of the study revealed that there are perceived significant factors hindering the implementation of entrepreneurial science education in public secondary schools in Akwa Ibom State, as well as negative effects on individual student and society, and that all the respondents agreed that the perceived strategies by science teachers should be adopted by the stake holders to improve the quality of science education curriculum for entrepreneurship. Based on the findings, recommendations were made among others, that entrepreneurial based education curriculum should be developed by stake holders in education and the implementations by science teachers ensured, having realized its importance in building the nation's economy and the development of self-reliant individuals.
\end{abstract}

\section{Introduction}

Many countries of the world see the objective of education as traditionally connected to harmony of physical and intellectual development of a person, developing a sense of observing, experiencing and creating the beautiful, and personality with a planned and organised creative and working attitude to nature and all the fields of human activities [1]. This means that the learner is a harmonically developed person from physical, intellectual, moral, aesthetic, and working-technical points of view-a versatile person.
Versatility means "creating realistic conditions for each human being to express and maximally develop all their human, individual, and generic and social opportunities.

Entrepreneurship is a concept derived from the activities of an entrepreneur. The word entrepreneur is an English term derived from the French word, entrepreneur, which is always seen from economic perspectives, hence Okpukpara [2] posits that an entrepreneur is a person who undertakes the organization of venture and its mechanism to maximize profits in the presence of risks.

Entrepreneurship education (Business Dictionary, [3] is the capacity and willingness to develop, organize and manage a business venture and its risks in order to make profit. Therefore, entrepreneurship science education is the science of induction, orientation and different forms of science teaching given to youth (people in general) to inculcate in them the potentials of beneficial adventure, which would enable them to produce needed goods and services, in spite of inherent risks.

Entrepreneurial and lifelong science education is the form of science education given to people to make them employers and not employees. Not only that, it is a continuous education because it can be acquired at any point of an individual's life. In addition, when acquired, the recipients are productive throughout their lifetime. Similarly, Adidu and Olannye [4] view entrepreneurial education as specialized training given to young men and women to acquire the skills, ideas and managerial activities and capacities for selfemployment rather than being employed for pay. It is a deliberate attempt to provide trainees with relevant knowledge, appropriate skills, competent and right attitude to effectively run or manage a business outfit.

Uduk [5] maintained that a look at the importance of Entrepreneurial and lifelong education is synonymous to looking at the importance of entrepreneurs themselves. The author sees the importance of entrepreneur to the economy of any country to include the following:

- Provision of variety of job opportunities: Venturing into entrepreneurship should create jobs, in business form. This implies 
that the more enterprising people are, the more the chances of investing in new businesses and the more new jobs are created.

- Economic growth: The entrepreneurse new businesses subsequently create wealth for those who directly or indirectly engage in those businesses. It specifies that the business owners, suppliers, financiers, distributors and many more people benefit from the wealth created by such new companies.

- Improved standard of living: Entrepreneurs engage in production of goods and services which are sold to generate income for the people and government. This brings about improved living standard of the consumers and producers alike.

- Investment opportunities: The new businesses established may open investment opportunities when they succeed. Most of these companies can enlist in stock exchange market for people to invest by way of share purchasing.

- Profit: Shareholders in successful businesses receive dividend at interval.

- Tax base of a government: The more entrepreneurs set up businesses, the more the government earn revenue from tax payment. The workers and entrepreneurs pay wages and taxes.

- Technological development: In a bid to maximize profit, business owners (entrepreneurs) get involved in competition. By so doing, new technology can be evolved.

From the foregoing, it means that the end product of entrepreneurial and lifelong education is the production of enterprising workforce to drive the private sector, thereby increasing the number of individuals participating in economic activities of the nation and reduction of government participation and intervention, thus, eradicating poverty and dependence.

Entrepreneurship, which is not a new concept in Nigeria has, however, grown in dimension for the services rendered by one man through his sole investment and on making profit to all efforts of getting things done through risk bearing mechanisms towards satisfying human wants [6]. Otomewo [7] in an attempt to conceptualize entrepreneurship sees it as a dynamic and social process where individuals alone or in collaboration identify opportunities for innovation and act upon these by transforming ideas into practical and targeted activities, whether in a social, cultural or economic content.

An entrepreneur therefore is a person vested with attitudes and behaviours that enable him understand his environment, people and their needs, take initiatives towards solving identified problems, set machinery on motion towards turning resources and materials into practical solutions to problems, bear risks and accepts success [6]. An entrepreneur is therefore not only an inventor, he is a life-long learner, a creative person, an initiator and a potential industrialist, a business person separated from his dream only by time and opportunity.

The destiny of any nation lies in the hand, the heart and mind of entrepreneurs since they shape, actualize, and drive their developmental dreams of any nation to reality. Thus, Knoakli \& Gogus [8], describe entrepreneurship as a process consisting of making the social change, creating social value or using the resources innovatively in order to satisfy the needs of the society. Akpomi [9] sees effective entrepreneurs as exceptional learners - learn everything from experience, learn by doing, they learn from what works and more importantly from what does not work.

A research conducted by UNESCO [10] shows that about 130 million young people of ages between 15-24 years in developing countries are classified as illiterate, among them being women with about 59\% illiteracy. And that a high number of illiterate youths and those with low schooling are living in rural areas and are never trained adequately, thus are poorly prepared for productive work. Going by this scheme whereby majority of the youths are not empowered with skills that are necessary for self-employment and sustainability, then their society will still lack behind development [11].

In Nigeria, governments, industries, Nongovernmental organization and the general public are much aware of this urgent need as the country strives to be globally competitive in the economic ties. This urgent need was reflected in the aim of the UN declaration of Education for Sustainable Development Plans (ESD) that was launched by UNESCO in 2005. This initiative seeks to integrate the inbuilt values in sustainable National Development into all aspects of learning including science education to encourage changes in attitude that permits for a more sustainable and independent society.

Sekenn in Amechi, Obed, Orlu \& Thomas, [10] observed that the only way to empower the masses is to provide them with adequate and qualitative education in order to make them job creators. Many developed countries of the world have considered Science, Technical and Vocational Education as relevant in equipping young people with the entrepreneurial skills that would 
enable them to engage in productive livelihood. Science education is the foundation of any nation's wealth and development as it provides the tools for technology. This is a kind of education that is meant to produce skilled man-power necessary to restore, revitalize, energise, operate and sustain the national economy and substantially reduce unemployment [12]. The National Policy on Education emphasizes that post-basic education shall provide entrepreneurial job specific skills for self-reliance and for agricultural, industrial, commercial and economic development.

It is a fact that the new world economy requires innovation, training, retraining in science education and other entrepreneurship training that will significantly favour the young learner in our schools. Entrepreneurship skills could help the youth acquire the mind set and know how necessary it is to make self-employment a variable career option. Therefore, the major aims of entrepreneurship education according to Oborah [13] should include but not limited to the following:

- To provide meaningful education for the youths, which would make them selfreliant and subsequently encourage them to derive profit and be self-dependent.

- To provide small and medium sized companies with the opportunities to receive qualified graduates who will receive training and tutoring in the skills relevant to the management of small business centres.

- To provide graduates with the training and support necessary to help them establish a career in small and medium sized businesses.

- To provide graduates with To provide the skills that will make them meet the manpower needs of the society.

- To provide graduates with enough training that will make them creative and innovative in identifying new business opportunities.

- To make graduates with enough training in risk management to make uncertainty amongst possible and easy.

- To stimulate industrial and economic growth of rural and less developed areas [13]

Again and Atakpa [14] maintains that one of the strategic aims of entrepreneurship is to produce graduates of international standards with appropriate knowledge and skills in their fields of study who will be highly employable and able to employ themselves. Realizing that entrepreneurship education has no subject boundaries, the questions now are; what factors hinder entrepreneurship science education in Akwa Ibom State? What are the effects of poor entrepreneurship science education on individuals and society? What strategies should be adopted to improve the quality of science education delivery for entrepreneurship?

\section{Statement of the Problem}

Entrepreneurial education has been introduced in the school curriculum across the nation's tertiary institutions in Nigeria as far back as 2010/2011 academic session. Students graduate out from these institutions without commensurable changes in the labour market. This is as a result of lack of continuity in the training for entrepreneurship. The nation is still in the problem of graduate unemployment. Since selfemployment intention which entrepreneurial education represents deals with the desire of a person to start a business in the future [15], education for entrepreneurship should start at the secondary school level of education.

However, it is regrettable to observe that there is no traces of science education curriculum or implementation in entrepreneurial education in Akwa Ibom state public secondary schools. The desire of any nation to have economic freedom and the opportunity for work-based experiences for youths is embedded on the level of entrepreneurial education of that nation. The problem of the study is to investigate science teachers' perception towards the implementation of entrepreneurial science education: its effects and the way forward in Akwa Ibom State, Nigeria.

\section{Purpose of the Study}

The purpose of the study was to appraise science teachers ${ }^{\text {ee }}$ perception towards the implementation of entrepreneurial science education, the effects on students and society and suggest strategies for the implementation of entrepreneurial science education in the state. Specifically, the study sought to achieve the following objectives:

1. Examine science teachers ${ }^{\text {ee }}$ perceived factors that hinder effective entrepreneurial science education in Akwa Ibom State, Nigeria.

2. Examine the science teachers ${ }^{\text {ee }}$ perceived negative influence of poor entrepreneurial science education curriculum on individuals and society.

3. Determine the science teachers ${ }^{\text {ee }}$ perceived strategies to be adopted to improve the quality of science education curriculum for entrepreneurship.

\section{Research Questions}

The following research questions where formulated to guide the study. 
1. What are the science teachers ${ }^{\text {ee }}$ perceived factors towards the non-implementation of entrepreneurial science education in public secondary schools in Akwa Ibom State, Nigeria?

2. To what extent are the science teachers ${ }^{\mathrm{ee}}$ perceived influence of poor entrepreneurial science education curriculum on individuals and society?

3. To what extent are the science teachers ${ }^{\text {ee }}$ perceived strategies effective to improve the quality of science education curriculum for entrepreneurship in the public secondary schools?

\section{Methods}

This study adopted a survey research design and was carried out in public secondary schools in Akwa Ibom state. The population for the study comprises all science teachers in the 243 public secondary schools in the state. The sample size for the study was 210 . A researcher-developed questionnaire titled "Science Teachers $^{\text {ee }}$ Perceived Factors Hindering the Implementation of Entrepreneurship Science Education and its Influence on Individuals and Society Questionnaire" (STEPFHIESES) was used for the data collection. The instrument was made up of three sections. Section A was on science teachers ${ }^{\text {ee }}$ perceived factors that hinder entrepreneurial science education in the state, section B on the influence of poor entrepreneurial science education curriculum on individual and society and section $\mathrm{C}$ on perceived strategies to be adopted to improve the quality of science education curriculum for entrepreneurship in the state. All sections of the questionnaire were structured on a 4-point rating scale of strongly Agreed (SA), Agreed (A), Disagreed (D) and strongly Disagreed (SD). In addition to the face validity done by three experts in the Department of Science Education of Akwa Ibom state University, Cronbach Alpha reliability method was also carried out to ensure internal consistency which was 0.92 and represented the reliability coefficient of the instrument.

\section{Results}

Table 1. Mean responses on perceived factors that hinder the implementation of entrepreneurial science education in secondary schools in Akwa Ibom State $(\mathrm{N}=210)$

\begin{tabular}{|l|l|l|l|l|}
\hline S/N & Factors hindering the implementations & $\mathrm{X}$ & $\mathrm{SD}$ & Remark \\
\hline 1 & Poor quality teaching staff & 3.78 & 1.37 & Agreed \\
\hline 2 & Poor teaching method & 4.05 & 1.15 & Agreed \\
\hline 3 & Lack of teaching facilities & 4.08 & 1.14 & Agreed \\
\hline 4 & Inadequate infrastructure & 3.85 & 1.35 & Agreed \\
\hline 5 & Poor funding of science education & 3.80 & 1.44 & Agreed \\
\hline 6 & Poor motivation of the teaching staff & 2.35 & 0.75 & Disagreed \\
\hline 7 & Poor attention to science education & 3.92 & 1.32 & Agreed \\
\hline 8 & Negative attitude to science by society & 2.92 & 1.44 & Agreed \\
\hline 9 & Irrelevant science education curriculum & 4.25 & 0.52 & Agreed \\
\hline 10 & Poor involvement of community based experience & 2.32 & 0.75 & Disagreed \\
\hline
\end{tabular}

\section{Weight mean 2.50}

The result on table 1 showed that the mean responses of eight items exceed the cutoff point of 2.50 while only two were below this value. This means that majority of the respondents used in the study agreed with eight listed items as being the factors hindering the implementation of entrepreneurial science education in secondary schools in Akwa Ibom State.

\section{Question 1:}

What are the science teachers ${ }^{\text {ee }}$ perceived factors towards the non-implementation of entrepreneurial science education in public secondary schools in Akwa Ibom State?

\section{Question 2:}

What are the effects of poor entrepreneurial science education curriculum on individual students/society as perceived by science teachers?

Table 2 indicates that the mean responses of all the items exceed 2.50. This implies that all the respondents used in the study agreed on all the listed items as being the effects of poor entrepreneurial science education curriculum on individual students/society as perceived by science teachers.

\section{Hypothesis 3:}

What perceived strategies can be adopted to improve the quality of science education curriculum for entrepreneurship in the state? 
Table 2. Mean responses on the effects of poor entrepreneurial science education curriculum on students and society $(\mathrm{N}=210)$

\begin{tabular}{|l|l|l|l|l|}
\hline S/N & Poor entrepreneurial science education curriculum & Mean $(\mathrm{x})$ & SD & Remark \\
\hline 1 & Increase in the students' drop out & 3.92 & 1.32 & Agreed \\
\hline 2 & Poor enrolment in science in higher education & 4.40 & 0.76 & Agreed \\
\hline 3 & Poor standard of science education & 4.36 & 0.76 & Agreed \\
\hline 4 & Decrease in the number of scientifically literate citizens & 2.92 & 1.44 & Agreed \\
\hline 5 & Increase in the number of white collar job seekers & 3.88 & 1.42 & Agreed \\
\hline 6 & Increase in the number of social deviants & 3.76 & 1.33 & Agreed \\
\hline 7 & Decline in the number of artisans & 3.35 & 1.46 & Agreed \\
\hline 8 & Lack of parents' interest in science education & 3.47 & 1.46 & Agreed \\
\hline 9 & Wastage of youthful energy & 4.33 & 1.63 & Agreed \\
\hline 10 & Poor transfer of scientific knowledge to personal problem solving & 3.67 & 1.50 & Agreed \\
\hline
\end{tabular}

Weight mean 2.50

Table 3. Mean responses on the perceived strategies to be adopted to improve the quality of science education curriculum for entrepreneurship $(\mathrm{N}=210)$

\begin{tabular}{|l|l|l|l|l|}
\hline S/N & Perceived Strategies & Mean $(\mathrm{x})$ & $\mathrm{SD}$ & Remarks \\
\hline 1 & Making the science curriculum relevant through reformation & 4.14 & 0.76 & Agreed \\
\hline 2 & $\begin{array}{l}\text { Organizing seminar and workshops for science teachers on teaching for } \\
\text { entrepreneurship }\end{array}$ & 3.98 & 1.32 & Agreed \\
\hline 3 & Adopting innovative and entrepreneurial oriented teaching methods & 4.26 & 1.33 & Agreed \\
\hline 4 & Adequate motivation of science teachers & 4.05 & 0.76 & Agreed \\
\hline 5 & Introducing Technical skills in science education & 3.88 & 1.22 & Agreed \\
\hline 6 & Provision of special fund for science education & 3.75 & 1.35 & Agreed \\
\hline 7 & Increase awareness on science education & 3.85 & 1.35 & Agreed \\
\hline 8 & Provision of entrepreneurial enhanced infrastructural facilities & 3.80 & 1.20 & Agreed \\
\hline 9 & Adoption of team teaching(scientific/technical) ingeed \\
\hline 10 & $\begin{array}{l}\text { Adoption of community-schools involvement in the entrepreneurial aspect } \\
\text { of science education }\end{array}$ & 4.05 & 1.15 & Agreed \\
\hline
\end{tabular}

Weight mean 2.50

Table 3 showed that the mean responses of the ten items exceed the cutoff point of 2.50. This implies that all the respondents used in the study agreed on the perceived strategies to be adopted to improve the quality of science education curriculum for entrepreneurship in the state.

\section{Discussion}

The result from Table 1 indicates that there are certain factors considered to hinder the smooth implementation of entrepreneurial science education in public secondary schools in Akwa Ibom State. Thus, these factors which are irrelevant curriculum and poor empowerment-based experience should be adequately handled to bring about effective implementation of entrepreneurial science education in the state and the country at large.

However, this is not in favour of the policy statement as contained in the National Policy on Education document [16] which include among others to acquire both physical and intellectual skills that will enable individuals to be self-reliant and useful members of the society. This is also not in line with the declarations of the World's Solution Forum [17] on Education 2030 which commits education agenda which is inclusive, equitable in quality, life long, holistic, ambitious and leaving no one behind. This declaration collaborates with the Darkar framework for Action on Education for all by UNESCO [18] which clearly stated that all young people and adults must be given opportunity to gain the knowledge and develop the values, attitudes and skills that will enable them to develop their capabilities to work, to participate fully in their society, to take control of their lives, and to continue learning, and become active agents in shaping their future and develop useful work related skills.

It should be noted that in the words of Aliu [19], entrepreneurship education is the learning directing towards diversifying in young people those skills, competencies, understanding and attributes which equip learners to be innovative, creative, initiators and successful managers and/or community businessmen. It is about increasing students' ability to participate and respond to societal changes [20].

Secondly, result in Table 2 revealed that there are some perceived negative influences of poor implementation of entrepreneurial science education in the state. The imperativeness of addressing these perceived negative influences are seen in the issues of many of the secondary school graduates not being able to engage themselves in any meaningful ventures 
capable of making them useful to themselves and others to the extent of bringing improvement to their standard of living.

This result showed that students and the society are deprived from the expected benefits as analysed by Agai in Joseph and Otuo [21], that entrepreneurship is a deliberate planned process of actions that are aimed at transforming a country's economy through primitive enterprise culture, enterprise creation and expansion and in turn creating employment for young men and women. Since the learners are not transformed through the entrepreneurship training, creating of employment and self-reliant becomes the negative influence and effect. The students lack the skills and ideas for managerial activities and expansion for selfemployment. The focus on realization of opportunities that makes entrepreneurial education distinct is blurred [22]. The learners are also deprived from the skills of life management, interaction, selffunded action and capacity for innovation that can grant the individual a hedge in the development and use of creative abilities and at the same time take creation and expansion initiatives, responsibilities and risk [23].

Finally, the finding on Table 3 showed that majority of the science teachers agreed with the perceived strategies as the strategies to be adopted to improve the quality of science education curriculum for entrepreneurship in the public secondary schools in Akwa Ibom State. This finding called for concerted efforts by the state and the federal governments to make proactive move on the implementation of entrepreneurial studies in science education and other fields of education to engage the secondary school leavers and graduates after school life to become useful citizens.

However, self-employment intentions are fundamental to understanding the entrepreneurship process because they form the undermining of new business. Since entrepreneurship occurs over time, self-employment intentions may then be considered as the essential strides in a developmental pattern of the science curriculum. The inclusion of the perceived agreed strategies in this study as itemized are of utmost important. Furthermore, for effective development of science education curriculum for entrepreneurship and its implementation, the following objectives as stressed by Paul [24] should be the guiding principles:

- To offer functional education for the youth that will enable them to be self-employed and self-reliant.

- To provide the secondary school leavers with adequate training that will enable them to be creative and innovative in identifying more business opportunities.
- To serve as a catalyst for economic growth and development, offer secondary school leavers with adequate training in risk management.

- To make certain bearing feasible, to reduce high rate of poverty, create employment generation, reduction in rural - urban migration.

- To provide the young school leavers with enough training and support that will enable them to establish a career in small and medium sized businesses.

- To inculcate the spirit of perseverance in the youths which will enable them to persist in any business venture they embarked on.

- To create a smooth change from conventional to the present day modern economy.

However, Igwe [25] suggested that durable and productive entrepreneurship education should look beyond entrepreneurial ventures. Rather, it should include entrepreneurship, where young entrepreneurs should be allowed to practise entrepreneurship education inside existing science education as a business. They should be engaged in commission or part time basis to invent ideas that would improve and broader the production capacities of existing businesses. The more such business expands through the insertion of entrepreneurship curriculum in science education, the more jobs will be created for the teaming population of the unemployed. Entrepreneurship Education should be the major key policy in promoting and empowering the youths in Nigeria.

\section{Conclusion}

Entrepreneurial science education in a new learning context in the state implies a different role for science teachers and educators. Teachers need to learn new skills and become lifelong learners themselves to keep up to date with new knowledge, pedagogical ideas, and technology. As learning becomes so collaborative, so too must teachers ${ }^{\text {ee }}$ professional development, which need to promote professional networks and learning organizations within schools and institutions.

There are evidences from the study that there are significant factors hindering the implementation of entrepreneurial science education in public secondary schools in the state. There are perceived significant negative influences of non-entrepreneurial science education curricula on individual students and society at large and there are no strategies adopted to improve the quality of science education curriculum for entrepreneurship in public secondary schools in the state. 
It is therefore concluded that urgent steps be taken by the ministry of education of the state in conjunction with all stake holders in secondary education to see to the development of entrepreneurial based science education curriculum and its implementation realizing the importance of entrepreneurship education in developing and empowering youths to be self-reliant in modern economy.

\section{Recommendations}

Based on the findings of the study, the following recommendations were made:

1. The Federal Ministry of Education in conjunction with Science Teachers Association should come out with a science curriculum with entrepreneurship base.

2. The entrepreneurship Science Education should be made compulsory to all students irrespective of their different future career interest. This is possible since every student of the senior secondary level is expected to offer at least one science subject.

3. Special seminars and workshops should be organized for science teachers in the secondary schools before the actual take off of the programme. This should be followed by regular retraining of the teachers until the implementation of the programme becomes stable in the system.

4. The teaching of entrepreneurship science education programme should be more practical based by the teachers. This will enable the students acquire more practical skills rather than theoretical knowledge.

5. The National Assembly should promulgate a law that makes for the provision of adequate fund by government for the implementation and management of entrepreneurship science education at the secondary school level in particular.

\section{References}

[1] Krulji, R., Kalapor, S.\& Kalic, R (2003). "Pedagogy eograd ${ }^{\text {ee }}$, National Youth Shalogy of the Republic of Serbia 55(05), pp 101-107.

[2] Okpukpara, B. E. (2011). Development entrepreneurship; Introduction to entrepreneurship, centre for Entrepreneurship Development Research Nsukka

[3] Business Dictionary (2017). "What is entrepreneurship?, Retrieved from www.businessdictionary.com>definition, on 2/4/2018.
[4] Adidu, F. A. and Olannye, A. P. (2006). Basic small business entrepreneurship: A modern approach, Royal pace publication, Agbor.

[5] Uduk, I. E. (2017). "Entrepreneurship and lifelong education: A panacea for economic emancipation of individuals and developing nations ${ }^{\text {ee }}$ Journal of Assertiveness 12 (1), pp $1-7$.

[6] Moemeke, C. D. (2013). "Innovating science education for technical entrepreneurship: The curriculum dimension"e, Business and Entrepreneurship Journal 2(r), pp 39-46.

[7] Otomewo, A. G. (2010). Integrating entrepreneurship in vocational and technical education: Challenges for sustainable economic development. A lead Paper presented at the 1st Annual conference of NAEAP in Delta State University, Ahaka, Nigeria, 13th-17th July.

[8] Knoakli T. and Gogus, N. (2013). "Pre-service teachers social entrepreneurship qualification scale: Validity and reliability study, Gazi University"e, Journal of Gazi Educational Faculty 33 (2),pp 313-391

[9] Akpomi, M.E. (2009) Achieving Millennium development goals through, teaching entrepreneurship education in higher education institution, European Journal of Social Sciences 8(1),67-74.

[10] UNESCO (2007). "Participation in former technical and vocational education and training programmes worldwide-An initial statistical study Canada"e, UNESCO Institute for statistics Montreale

[11] Amechi, O.J., Obed, O.O., Orlu, I, \& Thomas, C.T. (2007). "Impact of skill acquisition on entrepreneurship for wealth creation and sustainable development in technical colleges in Rivers State". African Journal of Educational Assessors, 3(3),pp94-103

[12] Amechi, S.W., Orlu, I. \& Obed, O.O. (2015). "Effect of insuring-based, technique on students performance in lathe machine operation, International Journal of Entrepreneurship Development Education and Science Research 3(2), pp1-12.

[13] Obora, H. J.O. (2006). "Business education and entrepreneurial development. A Survey of enterprice

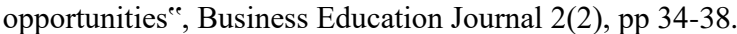

[14] Atakpa, R. A. (2011). "Entrepreneurship education: A sine qua-non in business education in Nigeria book of readings ${ }^{\text {ec }}$ Association of Business Educators of Nigeria, $(\mathrm{ABEN})$ 1, p. 11

[15] Davidson, P., (2009). "Determinant of entrepreneurial intentions. Proceedings RENT XI workshop, placeza, Italy, viewed on 16th September,2011 from httpj/eprintsant.au/archiveed000020761.

[16] FRN (2013) National Policy on Education, NERDC, Lagos

[17] World Education Forum (2015). "Draft declaration, Education 2030: Towards inclusive and equitable quality education and lifelong learning for alle, Retrieved from 
http://en.unesco.org/word education forum-2015/incheon declaration. retrieved January 15, 2017.

[18] UNESCO (2000). Education: Retrieved from http://www.unesco.org/new/en/education/themes. retrieved in January 15, 2017

[19] Aliu, S. (2014). Basic entrepreneurship education training for teachers in post-basic institutions. Retrieved from https://www.entrepreneurshipeducation for teachers/stock center/google.org, Retrieved in May, 2016

[20] Olorundare, and Kayode, (2014). "Entrepreneurship, education in Nigeria University: A tool for national transformation, Asia Pacific Journal of Educators and Education, 29(1), pp155 - 175.

[21] Joseph, E \& Otuo, O. H (2017). “Technical educational skills acquisition for entrepreneurial education and lifelong learning in developing countries: The way forward ${ }^{\text {ee }}$, Journal of assertiveness 12(1), pp $69-77$.

[22] Ayeni, O. G. \& Adesula, V. O. (2010). "Entrepreneur education: A vital force for poverty alleviation among N.C.E graduatese ${ }^{\text {ee }}$ Journal of Research in Education and Society $1(2 \& 3)$ pp111-116.

[23] Omade, A. A. (2012). "Entrepreneurship education: Key to job creation and sustainable national development in Nigeriae", African Journal of Education and Information Management 13(182), pp $52-56$

[24] Paul, E. O. (2005) Entrepreneurship education: in Ezems Priscilla N.; Paul Elizabeth O.; Anioke Beatris O.; Henri U. Anih (eds), Entrepreneurship in Education. OZYBEL Publishers, Enugu

[25] Igwe, L. E. B. (2009). "Management entrepreneurship education in a period of global depression", African Journal of Educational Research and Development 3 (2), pp20- 27. 